\title{
Understanding, Planning, and Implementation of HOTS by Senior High School Biology Teachers in Banjarmasin-Indonesia
}

\section{Siti Ramdiah}

STKIP PGRI Banjarmasin, Indonesia, sitiramdiah@gmail.com

\author{
Abidinsyah \\ STKIP PGRI Banjarmasin, Indonesia, bpabidin@yahoo.com
}

\section{Royani}

STKIP PGRI Banjarmasin, Indonesia, hmroyani@gmail.com

\section{Husamah}

Universitas Muhammadiyah Malang, Indonesia, usya_bio@umm.ac.id

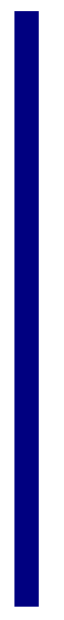
Higher-order Thinking Skills (HOTS) is significant for students and has to be trained and managed well by teachers. This study aims to describe the preparation of biology teachers in learning, to analyze the understanding of biology teachers about HOTS, and to examine the efforts of biology teachers in developing HOTS for high school students in Banjarmasin, Indonesia. The subject of this survey was forty-one senior high school biology teachers in the city of Banjarmasin who were involved in routine activities of MGMP (biology subject teacher working group). The research instrument is in the form of a modified questionnaire from previous researchers and has been validated by experts. The data were analyzed using descriptive statistic (percentage). The results showed that the senior high school biology teachers in Banjarmasin have prepared the lesson well, but this was not done consistently (continuously). Some teachers have not maximally prepared the lessons according to the recommended educational standards. The teacher's understanding of HOTS is broad enough, and they assume that HOTS really needs to be trained to students. However, it has not been described in their teaching activities because the HOTS aspect tends to be neglected (not well conducted).

Keywords: biology teacher, HOTS, senior high school, teaching, learning

\section{INTRODUCTION}

Teachers' professional ability is essentially a basic skill and deep understanding of the fluctuating demands in changing times (Ferguson-Patrick, 2018; Looney, Cumming, van Der Kleij, \& Harris, 2017; Mahini, Forushan, \& Haghani, 2012; Mintrom, 2014; Pianta,

Citation: Ramdiah, S., Abidinsyah, Royani, M., \& Husamah (2019). Understanding, Planning, and Implementation of HOTS by Senior High School Biology Teachers in Banjarmasin-Indonesia. International Journal of Instruction, 12(1), 425-440. https://doi.org/10.29333/iji.2019.12128a 
2016; Vighnarajah, Luan, \& Bakar, 2008). Teachers are required to be sensitive to the dynamics of the times, social, cultural, political, as well as technological developments (Assare, Mohammadi, Foroutan, \& Salehizadeh, 2016; Suyanto \& Jihad, 2013). These continuous development and change require an improved education and learning systems to generate a society that is able to compete and adapt to the changing times (Bangay, 2016; Christou, 2016; Pantiwati \& Husamah, 2017; Verger, 2014). On the basis of these demands, the learning process is expected to facilitate the empowerment of various competencies or life skills needed by students in the 21 st Century.

These life skills will be the qualified weapons for the students after graduation and when they plunge in the competitive employment era of globalization (Huang et al., 2010; Mcfarlane, 2013). Competence is not only limited to the concept of a variety of subjects, but also a variety of thinking skills or known as Higher-Order Thinking Skills (HOTS), such as metacognitive skill (Fauzi, 2013; Tanner, 2012), critical thinking (Ennis, 2011; Ghazivakili et al., 2014; Nazir \& Zabit, 2010; Phan, 2010), and creative thinking and self-regulation (Ersoy \& Baser, 2014; Husamah, Fatmawati, \& Setyawan, 2018; Tofade, Elsner, \& Haines, 2013). Various social skills and communication skills are also needed, including the ability to collaborate with others (Ladd et al., 2014; Ouellet, Sabbagh, Bergeron, Mayer, \& St-Onge, 2016). In fact, scientific processing skill needs to be empowered in the learning (Erkol \& Ugulu, 2014; Fauzi, Corebima, \& Zubaidah, 2016; Fauzi \& Ramadani, 2017; Gultepe, 2016) and the perception of teachers and parents is very important (Fomichova \& Misonou, 2018). From the various explanations, the empowerment of HOTS became one of the goals in the $21^{\text {st }}$-century learning process.

Students' HOTS empowerment effort is in line with the discourse to improve the quality of education through learning process to achieve learning outcomes (Kuswana, 2013). One of the main characteristics of successful learning can be reflected in a set of knowledge, attitude, and skills. These three components are formed by the habits and the strengthening of students' HOTS which are structured in design (Husamah et al., 2018). HOTS is substantial in the education process since one's thoughts can affect the ability, speed and effectiveness of learning, hence, HOTS is associated with students' learning. Students who are trained to think have a positive impact on the development of their education (Heong et al., 2011; Heong, Yunos, Osman, Sulong, \& Kiong, 2010). Thus, HOTS is seen as necessary for both teachers and students.

Teachers' profound role in developing HOTS for students is in planning and execution which should be seriously and consistently conducted (Adnan, Abdullah, Ahmad, Nawi, \& Ismail, 2017; Afandi, Sajidan, Akhyar, \& Suryani, 2018; Le, 2013; Shukla \& Dungsungnoen, 2016; Yeung, 2015). However, in practice, several problems still appear, affecting the ability and competence of the students. The results of the test and evaluation project suggest that the average achievement scores of Indonesian students for science, reading, and mathematics are at sixty second, sixty first, and sixty third levels of the total sixty-nine evaluated countries (PISA, 2015). South Kalimantan province stipulates that the try out result of high school/Islamic high school in biology is very concerning (Ramdiah, 2012). Teachers rarely train the component of thinking and metacognitive skill to the students (Ramdiah, 2015). The results of observations indicate 
that in 2016 there are obstacles in increasing the human resources shown by the low quality of teachers of $20.40 \%$. They have not been qualified and eligible to teach. The head of Education Office of South Kalimantan Province also gave information that there has been a decrease in the quality of high school graduates by 5\% from 2016 .

As an effort to map and improve the quality of Indonesian biology learning, various studies have been carried out on the schools' quality and performance of learning processes. Some studies focus on the level of teacher's ability to make and use learning plans (Ismomon, 2016; Lestari, 2015). Several other studies have discussed on the ability of teachers to design or carry out evaluation as well as the preparation of evaluation questions (Hariyatmi \& Riani, 2015; Nofiana, 2015). In addition, other studies were also conducted to look at general teacher competencies (Harahap, Hasanuddin, \& Abdullah, 2016; Panggabean \& Himawan, 2016; Roskia, Lestari, \& Dahlia, 2016). Furthermore, several studies have also been recorded to research the prospective Indonesian biology teachers (Anggraeni, 2009).

In a large scale, researches in Malaysia shows that students tend to have perceptions about the mastery of HOTS and the level of HOTS applications at low levels (Heong et al., 2010). Some other researches on language teachers in Selangor Malaysia project that teachers have a positive perception of the use of HOTS in learning and they believe that they significantly in need for training on how to teach by using HOTS (Mohamad, 2015). While research in Sarawak Malaysia on science teachers informs that the learning patterns related to HOTS need to be improved and made to be more effective. Science teachers require a professional development program to promote HOTS teaching (Subaili, 2014). In addition, several studies on Malay and English language teachers indicate that they are expected to teach both content and HOTS in their classrooms through integrated approach (Nagappan, 2001).

In accordance with the previous studies, ESL lecturers encounter challenges in facilitating the learning process with the integration of ICT as a supplementary tool in promoting HOTS (Ganapathy, Kaur, Singh, Kaur, \& Kit, 2017). Research on mathematics teachers in Malaysia signifies that they should play a role in developing HOTS thinking for students and acknowledging that some of the components related to it are still in progress and need to be improved (Adnan et al., 2017). Another study on history teachers has pointed out that educational change depends on what teachers' 'do' and 'think' as well as what the teachers' 'believe', which ultimately shapes the learning that supports the students' HOTS (Hashim, Osman, Arifin, Abdullah, \& Noh, 2015). A research in four leading higher educational institutions in Thailand reports that teachers have conducted various knowledge development and application strategies. The teachers' professional components such as designation, teaching experience, and qualification are significantly correlated with strategies used for accentuating HOTS, where students have shown medium level of HOTS (Shukla \& Dungsungnoen, 2016). In addition, another teacher-efficacy research displays that primary school teachers in New England may lack confidence in applying other assessment methods that promote HOTS in the classroom, especially in the form of formative assessment (Le, 2013). Meanwhile, a research in The Republic of Trinidad and Tobago provides information that teachers 
have a better perspective on the need to develop HOTS for students by planning and implementing cooperative and collaboration learning (Warner \& Kaur, 2017).

However, none of the previous studies has attempted to uncover the overview of HOTS's understanding, preparation of lesson planning by the teacher, as well as efforts to improve learning based on HOTS empowerment of students and science or biology teachers in Indonesia, especially in Banjarmasin, East Kalimantan. So far, there is only one research on twenty-seven junior high school mathematics teachers across seven provinces in Indonesia. The results denote that the teachers' knowledge as well as their ability to improve students' HOTS, solve the HOTS-based problems, and measure students' HOTS are still low (Retnawati, Djidu, Apino, \& Anazifa, 2017). Meanwhile, different study on 120 pre-service science teachers realizes the importance of HOTS to meet the challenges of the 21st century; their realization level is high. Therefore, cultivating awareness for HOTS learning is significant to foster the implementation of HOTS during pre-service education (Afandi et al., 2018). As the result, further research on high school biology teachers is very important to be conducted. The purposes of this study are: 1) to describe the preparation of biology learning by high school teachers in Banjarmasin; 2) to analyze the understanding of HOTS of biology teachers; and 3) to analyze the efforts of biology teachers in developing HOTS for high school students in Banjarmasin. The information obtained from this research is treated as the foundation for education policy makers (education authorities and Indonesian ministry of education and culture) and also important for the development of biology/science learning in Indonesia which reflects the needs of the twenty first century's skills.

\section{METHOD}

This is a survey study, providing information about the facts and descriptions of high school biology teachers in Banjarmasin Indonesia, the preparation of biology learning, and the understanding of High-order Thinking Skills, and the efforts of the teachers in developing HOTS for students in Banjarmasin's high schools. The population was all high school biology teachers in Banjarmasin. The sample of this study was forty-one high school biology teachers in Banjarmasin who were actively involved in routine biology subject teacher working group (Musyawarah Guru Mata Pelajaran/MGMP).

The research instrument is a questionnaire that has been validated by experts. The questionnaire has three main aspects, namely 1) aspect of learning preparation (Ramdiah, 2012, 2014, 2015), 2) aspect of knowledge and understanding of high-order thinking skills (modified from Hashim et al., 2015); and 3) aspect of developing students' high-order thinking skills (Nurmaliah, 2009).

Before being used as a data collection instrument, questionnaires were validated by four assessment experts and education experts, followed by a pilot test to test the validity of questionnaire items and instrument reliability. Cronbach's alpha and Pearson's correlation are used as a test of instrument validity and reliability. As a result, 40 items out of a total of 43 items tested were valid items and questionnaire instruments had high reliability with $r=0.83$. The questionnaire was then disseminated and filled by teachers 
who were participants in this study. Data collection is carried out for six months, from February to July 2018.

The questionnaire was then filled by high school biology teachers in Banjarmasin. The data were collected in the form of information preparation for learning biology, understanding of high-order thinking skills, as well as efforts in developing HOTS for high school students in Banjarmasin. Furthermore, the data were analyzed using descriptive statistics with percentages. This analysis aims to describe the data obtained from the results of questionnaires that have been filled by high school biology teachers in Banjarmasin.

\section{FINDINGS}

\section{Aspect of Learning Preparation}

Table 1 summarizes the information on teachers' responses towards the aspect of biology learning preparation in Banjarmasin's high schools. Based on the findings in Table 1, it can be interpreted that biology teachers in Banjarmasin High School have prepared the learning well. However, most of the respondents did not conduct routine preparation. It can be seen that in some items, respondents respond more with 'sometimes'. This condition lessens the innovative character of teachers in carrying out the learning process, especially in preparing learning documents and planning that are in accordance with educational standards.

In Indonesia, the learning process refers to the process standards which consist of planning, implementing, result evaluation, and learning process monitoring (Regulation of the Minister of Education and Culture of the Republic of Indonesia Number 22, Year 2016). A good design will provide a good learning result (Martin, 2011; Nesari \& Heidari, 2014). The data findings indicate that remedial activities are often scheduled by teachers as a program to improve learning outcomes. In another finding, it was found that $12.20 \%$ of teachers still did not develop and plan students' high-order thinking skills during the learning process. Furthermore, $75.61 \%$ of teachers sometimes do it. This means that the teacher deliberately does not make high-order thinking skills an important part of learning. This is in contrast with the assertions of Darling-hammond (2014); Ennis (2011); Fauzi (2013); Heong et al (2011); Magsino (2014); Ramadani, Fauzi, Sukmawati, \& Corebima (2015); and also Trilling and Fadel (2009), suggesting that learning while empowering higher-order thinking skills is the typical learning required for the twenty first century for students to answer the demands of time change. 
Table 1

Teachers' responses towards biology learning preparation (include HOTS aspect)

\begin{tabular}{llll}
\hline \multicolumn{1}{c}{ Questions } & \multicolumn{2}{c}{ Response Percentage } & \\
\cline { 3 - 4 } & Always & Sometimes & Never \\
\hline 1. Do you provide learning outcome indicators for & 56.10 & 43.90 & 0 \\
$\begin{array}{l}\text { evaluation needs? } \\
\text { 2. Do your learning media and work book support } \\
\text { the expected learning outcomes? }\end{array}$ & 78.05 & 21.95 & 0 \\
3. In these 2 years, are the students' biology & & & \\
$\quad \begin{array}{l}\text { learning outcomes in line with the specified } \\
\quad \text { Minimum Completion Criteria? }\end{array}$ & 4.87 & 92.68 & 2.44 \\
4. Do you plan for remedial learning? & 51.22 & 43.90 & 4.88 \\
5. Do you prepare evaluation rubric for students' & 39.02 & 56.10 & 4.88 \\
$\begin{array}{l}\text { learning result and HOTS aspects? } \\
\text { 6. Do you include the plan for HOTS }\end{array}$ & 12.20 & 75.61 & 12.20 \\
$\begin{array}{l}\text { development in your lesson planning? } \\
\text { 7. Do you implement learning strategies in }\end{array}$ & 56.10 & 43.90 & 0 \\
$\begin{array}{l}\text { teaching and learning processes? } \\
\text { 8. Is the learning in line with your planning? }\end{array}$ & 39.02 & 53.68 & 0 \\
\hline
\end{tabular}

The success of education in Indonesia is largely determined by the interrelated components of the relationship between students, teachers, and the interaction of both. This component is supported by other components, namely curriculum and learning apparatus (Malebye, 2016; Martin, 2011; Nesari \& Heidari, 2014). Teachers have a very important role in determining the quantity and quality of the teaching they carry out (Ferguson-Patrick, 2018; Hotaman, 2010; Looney et al., 2017; Mahini et al., 2012; Vighnarajah et al., 2008). Therefore, teachers have to think and plan carefully in improving learning opportunities for their students and improving teaching quality as well as reflection (Benade, 2015; Lamb, 2017). It is further explained that this effort requires changes in class organization, use of teaching methods, teaching and learning strategies, teacher attitudes and characteristics in managing the teaching and learning process. The teacher as the manager and facilitator of the teaching and learning process designs and develops learning materials and improves students' ability to listen and master the learning objectives. Besides, the design also supports teachers and designers in analyzing what is needed by students. In a structured learning environment, there is a process of gaining information, guiding actions, and providing information about the learning outcomes performed by students. Teachers can also provide more freedom to students while guiding them towards productive learning.

\section{Aspect of Understanding}

Teacher's understanding of aspects related to high-order thinking skills will affect the quality of learning that aims to empower this thinking skill (Hashim et al., 2015). The level of teacher's understanding in this study is presented in Table 2. 
Table 2

Teacher's understanding on HOTS

\begin{tabular}{lll}
\hline Questions & Responses (\%) & \\
\hline Do you understand about HOTS? & Very much & 2.44 \\
& Understand & 85.37 \\
& Do not understand & 12.20 \\
Do you need to train your students to develop their & Very necessary & 21.95 \\
HOTS? & Necessary & 73.17 \\
& Not necessary & 4.88 \\
In your opinion, is it important to deliver learning & Very important & 68.29 \\
outcomes before the learning process starts? & Important & 31.71 \\
\hline
\end{tabular}

Based on the results in Table 2, the understanding of biology teachers on high-order thinking skills analysis shows that $85.37 \%$ of teachers said they were very well informed and understood. Furthermore, $73.17 \%$ stated that they needed to train high-order thinking skills to students in biology learning. This information indicates that teachers have understood the demands that must be met by the world of education in the twenty first century (Darling-hammond, 2014; Heong et al., 2011; Huang et al., 2010). This is also confirmed in the next item, that in the implementation of biology learning, the teacher states that $68.29 \%$ of the learning objectives are very important to be delivered before the learning process. This is a very important part because in the learning process students have to know the goals to be achieved.

From these findings, if interpreted in depth, it is projected that the teachers have had broad knowledge of the importance of high-order thinking skills for students. This is in line with the opinion of Slavin (2008), where teachers need to know many aspects such as understanding the levels of development and needs of students, understanding learning, memory, problem solving skills, creativity, knowing how to set goals, and organizing activities designed to help students gain learning success. These are activities that must be carried out by the teacher, both in preparing or designing the learning process and applying students' thinking skills to achieve good quality learning. Learning-to-think skill is a strategic aspect in improving the quality of learning that is oriented towards achieving standard results (Kuswana, 2013). Furthermore, teaching strategies have a very important role where students can analyze, interpret, argue, synthesize, and evaluate their learning outcomes (Jerome, Lee, \& Ting, 2017; Mainali, 2012). This also relates to the teacher's professional component in educational qualifications, learning experience, research experience, training, and workshops. In addition to this, it was also stated that the strategy must be appropriate and effective with a thinker's attitude.

\section{Aspect to develop HOTS}

Teacher's effort to improve the learning process plays an important role in achieving the learning objectives. In this study, teacher's effort in developing students' high-level thinking skills during learning was also revealed. Applying the right learning activities (Al-Mubaid, Abukmail, \& Bettayeb, 2016; Ramirez \& Ganaden, 2008; Walker, 2003) and designing the right learning evaluation process (McNeill, Gosper, \& Xu, 2012) will 
optimize the empowerment of the expected thinking skill. Table 3 presents the information on teacher's effort to develop HOTS for students.

Table 3

Teacher's effort to develop HOTS for students.

\begin{tabular}{|c|c|c|c|c|c|c|}
\hline No & \multicolumn{2}{|c|}{ Questions } & \multicolumn{2}{|c|}{ Responses $(\%)$} & \multirow[b]{2}{*}{$\begin{array}{l}\text { Some- } \\
\text { times }\end{array}$} & \multirow[b]{2}{*}{ Never } \\
\hline 1 & \multicolumn{2}{|c|}{$\begin{array}{l}\text { Have you trained your students to apply the following } \\
\text { HOTS skills? }\end{array}$} & Very often & Often & & \\
\hline a. & \multicolumn{2}{|c|}{ Formulating problems/questions that lead to investigations } & 4.88 & 46.34 & 48.78 & 0 \\
\hline b. & \multicolumn{2}{|c|}{ Giving argument } & 4.88 & 80.49 & 14.63 & 0 \\
\hline c. & \multicolumn{2}{|l|}{ Formulating hypothesis } & 4.88 & 51.22 & 43.90 & 0 \\
\hline d. & \multicolumn{2}{|l|}{ Analyzing data } & 4.88 & 53.66 & 41.46 & 0 \\
\hline e. & \multicolumn{2}{|c|}{ Evaluating data } & 4.88 & 34.15 & 58.54 & 2.44 \\
\hline f. & \multicolumn{2}{|c|}{ Finding alternatives to solve problems } & 2.44 & 51.22 & 41.46 & 4.88 \\
\hline g. & \multicolumn{2}{|c|}{ Drawing conclusion } & 14.63 & 68.29 & 17.07 & 0 \\
\hline h. & \multicolumn{2}{|c|}{ Comparing by showing similarities and differences } & 2.44 & 80.49 & 14.63 & 2.44 \\
\hline i. & \multicolumn{2}{|c|}{ Stating cause and effect from a situation or problem context } & 4.88 & 56.10 & 36.59 & 2.44 \\
\hline j. & \multicolumn{2}{|c|}{ Giving logical reasons } & 4.88 & 78.05 & 17.07 & 0 \\
\hline k. & \multicolumn{2}{|l|}{ Stating or giving opinion } & 29.27 & 63.41 & 7.32 & 0 \\
\hline 1. & \multicolumn{2}{|c|}{ Pointing/grouping } & 7.32 & 70.73 & 21.95 & 0 \\
\hline $\mathrm{m}$. & \multicolumn{2}{|c|}{$\begin{array}{l}\text { Implementing/conducting a certain principal/concept that } \\
\text { has been understood to solve problems }\end{array}$} & 7.32 & 39.02 & 41.46 & 12.19 \\
\hline n. & \multicolumn{2}{|c|}{ Defining a concept } & 20.00 & 47.50 & 32.50 & 0 \\
\hline o. & \multicolumn{2}{|l|}{ Deducting } & 2.44 & 34.15 & 58.54 & 4.88 \\
\hline p. & \multicolumn{2}{|c|}{ Inducting } & 2.44 & 36.59 & 56.10 & 4.88 \\
\hline q. & \multicolumn{2}{|c|}{ Making a decision and implementing a solution } & 7.32 & 51.22 & 39.02 & 2.44 \\
\hline r. & Identifying the unknown t & be learnt & 7.32 & 58.54 & 31.70 & 2.44 \\
\hline s. & $\begin{array}{l}\text { Identifying what has bee } \\
\text { topic }\end{array}$ & vn from the further learnt & 4.88 & 53.66 & 39.02 & 2.44 \\
\hline t. & Identifying what will be le & ther from the learnt topic & 2.44 & 56.10 & 39.02 & 2.44 \\
\hline u. & $\begin{array}{l}\text { Stating/conversing on way } \\
\text { assignment }\end{array}$ & arn a topic or to answer an & 0 & 68.29 & 26.83 & 4.88 \\
\hline v. & $\begin{array}{l}\text { Speaking/noting difficulti } \\
\text { topic discussion or assign }\end{array}$ & $\begin{array}{l}\text { are experienced during } \\
\text { mpletion }\end{array}$ & 14.63 & 46.34 & 36.59 & 2.44 \\
\hline w. & $\begin{array}{l}\text { Speaking/noting the im } \\
\text { difficulties in topic discus }\end{array}$ & $\begin{array}{l}\text { ted ways to overcome } \\
\text { assignment completion }\end{array}$ & 0 & 51.22 & 46.34 & 2.44 \\
\hline $\mathrm{x}$. & Planning and organizing le & processes & 14.63 & 63.41 & 19.51 & 2.44 \\
\hline $\begin{array}{l}\text { y. } \\
\text { y. }\end{array}$ & Reporting learning results & ect in a creative manner & 4.88 & 63.41 & 29.27 & 2.44 \\
\hline 2 & $\begin{array}{l}\text { In which format is the eva } \\
\text { how often)? }\end{array}$ & given to students (and & Very often & Often & Some-times & Never \\
\hline & & Multiple choice & 29.27 & 65.85 & 0 & 4.88 \\
\hline & & Cause and effect & 0 & 7.32 & 29.27 & 63.41 \\
\hline a. & Objective test & Matching & 2.44 & 7.32 & 48.78 & 41.46 \\
\hline & & Short answer & 17.07 & 63.41 & 9.76 & 9.76 \\
\hline & & Mention.... & 17.07 & 46.34 & 26.83 & 9.76 \\
\hline & & Is..... & 12.20 & 48.78 & 17.07 & 21.95 \\
\hline & & Explain.... & 24.39 & 68.29 & 2.44 & 4.88 \\
\hline & & Compare.... & 12.20 & 48.78 & 29.27 & 9.76 \\
\hline & & Why.... & 14.63 & 60.98 & 12.20 & 12.20 \\
\hline & & How...... & 14.63 & 58.54 & 14.63 & 9.76 \\
\hline b. & Subjective test (question & Organize..... & 4.88 & 41.46 & 39.02 & 14.63 \\
\hline & & Do.... & 2.44 & 31.70 & 48.78 & 17.07 \\
\hline & & Measure..... & 7.32 & 14.63 & 46.63 & 31.70 \\
\hline & & Observe... & 2.44 & 31.70 & 39.02 & 26.83 \\
\hline & & Summarize... & 9.76 & 34.15 & 39.02 & 17.07 \\
\hline & & $\begin{array}{l}\text { What do you think } \\
\text { of... }\end{array}$ & 7.32 & 24.39 & 46.34 & 21.95 \\
\hline & & Portfolio & 9.76 & 48.78 & 29.27 & 9.76 \\
\hline & & Performance & 2.44 & 41.46 & 26.83 & 29.27 \\
\hline c. & Alternative assessments & Project based scoring & 0 & 26.83 & 56.10 & 17.07 \\
\hline & & Journal & 2.44 & 12.20 & 46.34 & 39.02 \\
\hline
\end{tabular}

International Journal of Instruction, January $2019 \bullet$ Vol.12, No.1 
Based on the analysis results of biology teachers' efforts in developing high-order thinking skills in Banjarmasin as presented in Table 3, it is proven that biology teachers have implemented good learning programs, but have not maximally applied HOTS. Not all good learning may empower HOTS for students, because in empowering these thinking skills, certain learning strategies and activities should be implemented (Jerome et al., 2017; Mainali, 2012). Based on the obtained results, the responses of respondents revealed those important aspects of training high-order thinking skills tend to be very rare (sometimes) or an average of only $50 \%$. Aspects in question are like formulating a problem /question that leads to investigation, giving arguments, formulating hypotheses, analyzing data, evaluating data, finding alternative problem solving, applying/implementing a principle/concept that has been understood, doing deduction and induction, talking/noting the method taken in dealing with difficulties experienced in learning a topic or completing a task.

If analyzed deeper, these data findings illustrate that teacher's effort in training Highorder Thinking Skill for high school students in Banjarmasin is very low. This also shows that the teacher has not applied his insights about HOTS in designing and implementing meaningful learning processes for students. Therefore, it can concluded that the findings are in line with the previous findings which inform that not many teachers make improvements in students' ability to think in high-level (Hasan, Tumbel, \& Duran Corebima, 2013). It is further explained that critical thinking is a high-order thinking activity that should be developed continuously so that students grow their intellectual skills and is evaluated to always be developed. This ability is carried out for students to be able to determine and select various kinds of information from different sources, to process this information in creative and logical behavior, reject it, analyze it and draw conclusions as well as to be able to conduct information maintenance. A student is said to have applied high-order thinking skill when he/she knows how to use critical and creative thinking skills (Heong et al., 2011). However, not all students have the expected skills; therefore, students should be encouraged, taught, and helped to experience a high-order thinking process.

Based on the findings, it can also be concluded that there is a gap between respondents' opinions which states that there is a great need to train high-level thinking skills for students, but in the design and implementation of learning processes these important aspects were rarely done. The teacher can train these aspects of high-order thinking skill continuously that are strengthened contextually and conceptually analyzed (Shukla \& Dungsungnoen, 2016). In addition, suitable teaching strategy has a role in instilling these aspects. Higher-order thinking skill can be facilitated in two contexts, namely 1). The thought process is needed to solve problems and make everyday decisions, 2). Mental process is needed to get the benefits of instruction such as comparing, evaluating, justifying and making conclusions.

Empowering HOTS is essential for the twenty first century learning. The characteristics of science learning are suitable in the empowerment process. It is due to the fact that the field of science education focuses on logical understanding, emotional comprehension, linkages, responsibilities, moral reasoning, and various thinking skills such as intuitive 
thinking, hypothesis testing, problem solving and critical thinking, all of which are components of higher ordered thinking skills (Garcia, 2015). The empowerment of these skills is considered essential as students are trained to make the best decisions in analyzing arguments and produce insights into certain meanings and interpretations as the product of logical reasoning patterns. In addition, higher-order thinking skills enable students to see concepts holistically and reflect an effective, curious, sceptical, flexible thinker attitude, able to revise beliefs, be analytical, persistent by thinking deeply, and sensitive to the context of current issues (Shukla \& Dungsungnoen, 2016). Unfortunately, based on the data obtained from this study, the empowerment of highorder thinking skills is still not optimally held by high school biology teachers in Banjarmasin. Based on this information, the government and educational institutions should reinforce educational regulation emphasizing the importance of empowering HOTS to students and facilitate teachers to improve their ability to design and implement HOTS learning.

\section{CONCLUSION}

The research findings indicate that high school biology teachers in Banjarmasin have prepared learning well, but this is not carried out consistently (continuously), and some have not maximally prepared learning in accordance with the recommended education standards. Teachers already have moderate understanding of HOTS and are aware of the needs to practice HOTS for their students. The teacher's efforts in developing HOTS have not been realized and are less described in their teaching activities because the HOTS aspect tends to be ignored. Further researches should be conducted to measure the level of HOTS of the students in Banjarmasin, to study various local government policies (education offices), and multiple efforts to train HOTS by improving the quality of learning.

\section{ACKNOWLEDGEMENT}

This publication is part of a research report that has been funded by The Ministries of Research, Technology, and Higher Education, the Republic of Indonesia through Competency-Based Research grants, coordinated by Private University Coordination (Region 11, Kalimantan) with contract number: 530/Contract-Research/K11/KM/2018. Thank you for the opportunity.

\section{REFERENCES}

Adnan, M., Abdullah, M. F. N. L., Ahmad, C. N. C., Nawi, N. M., \& Ismail, S. (2017). Perceptions of Mathematics Teachers in Higher Order Thinking Skills (HOTS) in Kuala Langat District Secondary School. The Social Sciences, 12(11), 1963-1965.

Afandi, A., Sajidan, S., Akhyar, M., \& Suryani, N. (2018). Pre-service Science Teachers Perception about High Order Thinking Skills (HOTs) in 21st Century. International Journal of Pedagogy and Teacher Education (IJPTE), 2(1), 301-308.

Al-Mubaid, H., Abukmail, A., \& Bettayeb, S. (2016). Empowering deep thinking to support critical yhinking in teaching and learning. In Proceedings of the 2016 ACM SIGMIS Conference on Computers and People Research - SIGMIS-CPR '16 (pp. 69- 
75). https://doi.org/10.1145/2890602.2890606

Anggraeni, S. (2009). Sudahkan calon guru biologi merencanakan pembelajaran biologi yang sesuai dengan hakekat sains? In Prosiding Seminar Nasional Penelitian, Pendidikan, dan Penerapan MIPA (pp. 340-348). Yogyakarta: Fakultas MIPA UNY.

Assare, A. R., Mohammadi, M., Foroutan, M., \& Salehizadeh, M. (2016). The Impact of Globalization on Education. Journal of Administrative Management, Education and Training (JAMET), 12(5), 27-33.

Bangay, C. (2016). Protecting the Future: The Role of School Education in Sustainable Development - An Indian Case Study. International Journal of Development Education \& Global Learning, 8(1), 5-19.

Benade, L. (2015). Teachers' Critical Reflective Practice in the Context of Twenty-first Century Learning. Open Review of Educational Research, 2(1), 42-54. https://doi.org/10.1080/23265507.2014.998159

Christou, T. M. (2016). 21 st -century learning, educational reform, and tradition: Conceptualizing professional development in a progressive age. Teacher Learning and Professional Development, 1(1), 61-72.

Darling-hammond, L. (2014). Constructing 21st-Century Teacher Education, 57(3). https://doi.org/10.1177/0022487105285962

Ennis, R. H. (2011). The Nature of Critical Thinking: An Outline of Critical Thinking Dispositions and Abilities.

Erkol, S., \& Ugulu, I. (2014). Examining Biology Teachers Candidates' Scientific Process Skill Levels and Comparing These Levels in Terms of Various Variables. Procedia - Social and Behavioral Sciences, 116, 4742-4747. https://doi.org/10.1016/j.sbspro.2014.01.1019

Ersoy, E., \& Baser, N. e. (2014). The effects of Problem-Based Learning method in higher education on creative thinking. Procedia - Social and Behavioral Sciences, 116, 3494-3498. https://doi.org/10.1016/j.sbspro.2014.01.790

Fauzi, A. (2013). Pengaruh kemampuan akademik terhadap keterampilan metakognitif, hasil belajar biologi, dan retensi siswa SMA Kelas X dengan penerapan strategi pembelajaran Cooperative Script di Malang. Universitas Negeri Malang. https://doi.org/10.13140/RG.2.2.24659.99363

Fauzi, A., Corebima, A. D., \& Zubaidah, S. (2016). The utilization of ferns as a model organism for studying natural polyploidization concept in genetics course. In International Conference on Education (pp. 51-58). Malang: Universitas Negeri Malang.

Fauzi, A., \& Ramadani, S. D. (2017). Learning the Genetics Concepts through Project Activities Using Drosophila Melanogaster: A Qualitative Descriptive Study. JPBI (Jurnal Pendidikan Biologi Indonesia), 3(3), 238-247. 
https://doi.org/10.22219/jpbi.v3i3.4540

Ferguson-Patrick, K. (2018). The Importance of Teacher Role in Cooperative Learning: The Effects of High-Stakes Testing on Pedagogical Approaches of Early Career Teachers in Primary Schools. Education 3-13, 46(1), 89-101. https://doi.org/10.1080/03004279.2016.1189946

Fomichova, K., \& Misonou, T. (2018). Parents' Perceptions on Previous and Current Science Education System in Japan. JPBI (Jurnal Pendidikan Biologi Indonesia), 4(2), 113-122. https://doi.org/10.22219/jpbi.v4i2.5702

Ganapathy, M., Kaur, M., Singh, M., Kaur, S., \& Kit, L. W. (2017). Promoting Higher Order Thinking Skills via Teaching Practices. 3L: The Southeast Asian Journal of English Language Studies, 23(1), 75-85. https://doi.org/10.17576/3L-2017-2301-06

Garcia, L. C. (2015). Environmental science issues for higher-order thinking skills (HOTS) development : A case study in the Philippines. In E. G. S. Daniel (Ed.), Biology Education and Research in a Changing Planet (pp. 45-54). Singapore: Springer Science+Business Media. https://doi.org/10.1007/978-981-287-524-2

Ghazivakili, Z., Norouzi Nia, R., Panahi, F., Karimi, M., Gholsorkhi, H., \& Ahmadi, Z. (2014). The Role of Critical Thinking Skills and Learning Styles of University Students in Their Academic Performance. Journal of Advances in Medical Education \& Professionalism, 2(3), 95-102.

Gultepe, N. (2016). High School Science Teachers' Views on Science Process Skills. International Journal of Environmental and Science Education, 11(5), 779-800. https://doi.org/10.12973/ijese.2016.348a

Harahap, V. Y., Hasanuddin, \& Abdullah. (2016). Kompetensi Profesionalisme Guru Biologi di Banda Aceh. Jurnal EduBio Tropika, 4(2), 1-52.

Hariyatmi, \& Riani, H. A. A. (2015). Kemampuan guru biologi SMA dalam penyusunan penilaian autentik (authentic assesment) sebagai evaluasi pembelajaran. In Seminar Nasional XII Pendidikan Biologi FKIP UNS 2015 (pp. 861-865). Surakarta: Pendidikan Biologi FKIP UNS.

Hasan, S., Tumbel, F. M., \& Duran Corebima, A. (2013). Empowering Critical Thinking Skills in Indonesia Archipelago: Study on Elementary School Students in Ternate. Journal of Modern Education Review, 3(11), 852-858.

Hashim, A. T., Osman, R., Arifin, A., Abdullah, N., \& Noh, N. M. (2015). Teachers' Perception on Higher Order Thinking Skills as an Innovation and Its Implementation in History Teaching. Australian Journal of Basic and Applied Sciences, 9(32), 215-221.

Heong, Y. M., Othman, W. B., Yunos, J. Bin, Kiong, T. T., Hassan, R. Bin, Mohaffyza, M., \& Mohamad, B. (2011). The Level of Marzano Higher Order Thinking Skills among Technical Education Students, 1(2).

Heong, Y. M., Yunos, J. B. M., Osman, N. binti, Sulong, S. binti I., \& Kiong, T. T. 
(2010). The perception of student on matering the level of higher order thinking skills in technical education subjects. In RCEE \& RHEd2010 (pp. 1-6). Kuching, Sarawak.

Hotaman, D. (2010). The Teaching Profession: Knowledge of Subject Matter, Teaching Skills and Personality Traits. Procedia - Social and Behavioral Sciences, 2(2), 14161420. https://doi.org/10.1016/j.sbspro.2010.03.211

Huang, D., Leon, S., Hodson, C., La, D., Obregon, T. N., \& Rivera, G. (2010). Preparing students for the 21st century: Exploring the effect of afterschool participation on students' collaboration skills, oral communication skills, and selfefficacy. Los Angeles. https://doi.org/10.1037/e642072011-001

Husamah, H., Fatmawati, D., \& Setyawan, D. (2018). OIDDE Learning Model: Improving Higher Order Thinking Skills of Biology Teacher Candidates. International Journal of Instruction, 11(2). https://doi.org/10.12973/iji.2018.11217a

Ismomon, H. (2016). Penggunaan Perangkat Pembelajaran Biologi Pada Sekolah Menengah Atas Negeri Kabupaten Simeulue. Jurnal Ilmiah Mahasiswa Pendidikan Biologi, 1(1), 55-70.

Jerome, C., Lee, J. A.-C., \& Ting, S.-H. (2017). What students Really Need: Instructional Strategies that Enhance Higher Order Thinking Skills (HOTS) among Unimas Undergraduates. International Journal of Business and Society, 18(4), 661668 .

Kuswana, W. . (2013). Taksonomi berpikir. Bandung: PT Remaja Rosdakarya.

Ladd, G. W., Kochenderfer-Ladd, B., Visconti, K. J., Ettekal, I., Sechler, C. M., \& Cortes, K. I. (2014). Grade-school Children's Social Collaborative Skills: Links with Partner Preference and Achievement. American Educational Research Journal, 51(1), 152-183. https://doi.org/10.3102/0002831213507327

Lamb, J. (2017). How do Teachers Reflect on Their Practice? A Study into How Feedback Influences Teachers' Reflective Practice. The STeP Journal, 4(4), 94-104.

Le, L. K. (2013). Teacher-efficacy for using HOTS pedagogy in the classroom. Master's Theses, 406. Retrieved from http://digitalcommons.uconn.edu/gs_theses/406

Lestari, M. D. (2015). Analisis kemampuan guru biologi sma di Kota Semarang dalam membuat rencana pelaksanaan pembelajaran (RPP) berdasarkan Kurikulum 2013. Universitas Negeri Semarang.

Looney, A., Cumming, J., van Der Kleij, F., \& Harris, K. (2017). Reconceptualising the Role of Teachers as Assessors: Teacher Assessment Identity. Assessment in Education: Principles, Policy and Practice, (January), 1-26. https://doi.org/10.1080/0969594X.2016.1268090

Magsino, R. M. (2014). Enhancing Higher Order Thinking Skills in a Marine Biology Class through Problem-Based Learning. Asia Pacific Journal of Multidisciplinary Research, 2(5), 1-6. 
Mahini, F., Forushan, Z. J.-A., \& Haghani, F. (2012). The Importance of Teacher's Role in Technology-Based Education. Procedia - Social and Behavioral Sciences, 46, 16141618. https://doi.org/10.1016/j.sbspro.2012.05.348

Mainali, B. P. (2012). Higher Order Thinking in Education. Academic Voices: A Multidisciplinary Journal, 2(1), 5-10.

Malebye, L. M. (2016). Teacher involvement in curriculum development, 7(9), 81.

Martin, F. (2011). Instructional Design and the Importance of Instructional Alignment. Community College Journal of Research and Practice, 35(12), 955-972. https://doi.org/10.1080/10668920802466483

Mcfarlane, D. A. (2013). Understanding the Challenges of Science Education in the 21 st Century: New Opportunities for Scientific Literacy. International Letters of Social and Humanistic Sciences, 4, 35-44. https://doi.org/10.18052/www.scipress.com/ILSHS.4.35

McNeill, M., Gosper, M., \& Xu, J. (2012). Assessment Choices to Target Higher Order Learning Outcomes: The Power of Academic Empowerment. Research in Learning Technology, 20(3), 283-296. https://doi.org/10.3402/rlt.v20i0.17595

Mintrom, M. (2014). Creating Cultures of Excellence: Strategies and Outcomes. Cogent Education, 1(1), 1-13. https://doi.org/10.1080/2331186X.2014.934084

Mohamad, S. N. binti. (2015). Teachers' Perception on the Integration of HOTS in Language Teaching. International Journal of Technical Research and Applications, (22), 42-44.

Nagappan, R. (2001). The Teaching of Higher-Order Thinking Skills in Malaysia. Journal of Southeast Asian Education, 2(1), 1-21.

Nazir, M., \& Zabit, M. (2010). Problem-based Learning on Students' Critical Thinking Skills in Teaching Business Education in Malaysia: A literature Review. American Journal of Business Education, 3(6), 19-32.

Nesari, A. J., \& Heidari, M. (2014). The Important Role of Lesson Plan on Educational Achievement of Iranian EFL Teachers' Attitudes. International Journal of Foreign Language Teaching \& Research, 3(5), 25-31.

Nofiana, M. (2015). Kualitas Penulisan Butir Soal Ujian Nasional Biologi Tahun 2014/2015 ditinjau dari aspek teoritik. Saintifika, 17(1), 1-13.

Nurmaliah, C. (2009). Keterampilan berpikir kritis, metakognitif, dan hasil belajar biologi siswa SMPN di Kota Malang. State Univer, Malang, Indonesia.

Ouellet, K., Sabbagh, R., Bergeron, L., Mayer, S., \& St-Onge, C. (2016). Exploring Residents Spontaneous Collaborative Skills in a Simulated Setting Context: An Exploratory Study on CanMEDS Collaborator Role. Advances in Medical Education and Practice, 7, 401-405. https://doi.org/10.2147/AMEP.S101698 
Panggabean, M. S., \& Himawan, K. K. (2016). The Development of Indonesian Teacher Competence Questionnaire. Journal of Educational, Health, and Community Psychology, 5(2), 1-15.

Pantiwati, Y., \& Husamah. (2017). Self and Peer Assessments in Active Learning Model to Increase Metacognitive Awareness and Cognitive Abilities. International Journal of Instruction, 10(4), 185-202. https://doi.org/10.12973/iji.2017.10411a

Phan, H. P. (2010). Critical thinking as a self-regulatory process.

Pianta, R. C. (2016). Teacher-student Interactions: Measurement, Impact, Imrpovement, and Policy. Policy Insights from the Behavioral and Brain Sciences, 3(1), 98-105. https://doi.org/10.1177/2372732215622457

PISA. (2015). Result from PISA. 2015.

Ramadani, S. D., Fauzi, A., Sukmawati, I., \& Corebima, A. D. (2015). Perbandingan potensi strategi pembelajaran cooperative script dan reciprocal teaching dalam memberdayakan keterampilan metakognitif, hasil belajar Biologi, dan retensi siswa SMA. In Proceedings of the 2nd Seminar \& Workshop Nasional Biologi, IPA, dan Pembelajarannya FMIPA UM (pp. 655-661). Malang: Biologi FMIPA UM.

Ramdiah, S. (2012). Peta konsep pada pembelajaran biologi di SMA Kota Banjarmasin dalam upaya meningkatkan keterampilan metakognitif. In Prosiding Seminar Nasional MIPA dan Pembelajaran. Malang, Indonesia: State University of Malang.

Ramdiah, S. (2014). The effect of preview, question, read, reflect, recite, review (PQ4R) learning strategy combined with concept mapping and gender towards the metacognitive skill, the critical thinking, biology cognitive learning result, and the retention of senior high sc. State University of Malang.

Ramdiah, S. (2015). Keterampilan Metakognitif Guru-guru Biologi Sekolah Menengah Atas Kota Banjarmasin. Jurnal Pendidikan Hayati, 1(4), 71-80.

Ramirez, R. P. B., \& Ganaden, M. S. (2008). Creative Activities and Students' Higher Order Thinking Skills. Education Quarterly, 66(1), 22-33.

Retnawati, H., Djidu, H., Apino, E., \& Anazifa, R. D. (2017). Teachers' Knowledge about Higher-order Thinking Skills and its Learning Strategy. Problems of Education in The 21st Century, 76(2), 215-230.

Roskia, D., Lestari, R., \& Dahlia. (2016). Analisis Kompetensi Profesional Guru Biologi SMA di Kecamatan Rambah Hilir. Jurnal Mahasiswa FKIP Universitas Pasir Pengaraian, 2(1), 1-7.

Shukla, D., \& Dungsungnoen, A. P. (2016). Student's Perceived Level and Teachers' Teaching Strategies of Higher Order Thinking Skills; A Study on Higher Educational Institutions in Thailand. Journal of Education and Practice, 7(12), 211-219.

Slavin. (2008). Psikologi pendidikan teori dan praktek (1st ed.). Jakarta: Indeks. 
Subaili, A. B. H. (2014). Exploring teachers' experiences on integration of higher order thinking skills (HOTS) in teaching of science. University Malaysia Sarawak.

Suyanto, \& Jihad, A. (2013). Menjadi guru professional, strategi meningkatkan kualifikasi dan kualitas guru di era global. Jakarta: Erlangga.

Tanner, K. D. (2012). Promoting Student Metacognition. CBE Life Sciences Education, 11(2), 113-120. https://doi.org/10.1187/cbe.12-03-0033

Tofade, T., Elsner, J., \& Haines, S. T. (2013). Best Practice Strategies for Effective Use of Questions as a Teaching Tool. American Journal of Pharmaceutical Education, 77(7), 1-9. https://doi.org/10.5688/ajpe777155

Trilling, B., \& Fadel, C. (2009). 21st Century Skills: Learning for Life in Our Times. San Francisco: Jossey-Bass.

Verger, A. (2014). Why do Policy-makers Adopt Global Education Policies? Toward a Research Framework on the Varying Role of Ideas in Education Reform. Current Issues in Comparative Education, 16(2), 14-29.

Vighnarajah, Luan, W. S., \& Bakar, K. A. (2008). The Shift in the Role of Teachers in the Learning Process. European Journal of Social Sciences, 7(2), 33-41.

Walker, S. E. (2003). Active Learning Strategies to Promote Critical Thinking. Journal of Athletic Training, 38(3), 263-267.

Warner, S., \& Kaur, A. (2017). The Perceptions of Teachers and Students on a 21st Century Mathematics Instructional Model. International Electronic Journal of Mathematics Education, 12(2), 193-215. 